\title{
A SUBJETIVIDADE EM TEMPO DE SUBJETIVIDADES: UM ENSAIO SARTRIANO A PARTIR DE UM CAFÉ
}

RESUMO: O presente ensaio pretende fazer uma leitura da efervescência da subjetividade humana no período do isolamento social, medida adotada devido à pandemia do Covid-19. Na interdisciplinaridade entre Filosofia, Sociologia e Arte, com uma linguagem metafórica e literária, se apresenta a necessidade de fomento e análise das situações cotidianas como meio ordinário de enriquecimento intelectual e reflexão crítica da realidade, frente ao embrutecimento e consequentes problemáticas sociais, educativas e pessoais advindas do isolamento social. Numa mudança abrupta da normalidade cotidiana, cada sujeito humano foi obrigado a repensar suas práticas e relações individuais e sociais. Em uma conversa entre Jean-Paul Sartre, Edith Piaf e Zygmunt Bauman é possível redescobrir a importância da subjetividade em tempo de subjetividades.

Palavras-chaves: Subjetividade; Filosofia; Pandemia Covid-19.

\section{SUBJECTIVITY IN TIMEOF SUBJECTIVITIES A SARTRIAN TEST FROM A COFFEE}

ABSTRACT: This essay intends to read the effervescence of human subjectivity during the period of social isolation, a measure adopted due to the Covid-19 pandemic. In the interdisciplinarity between Philosophy, Sociology and Art, with a metaphorical and literary language, there is a need to foster and analyze everyday situations as an ordinary means of intellectual enrichment and critical reflection of reality, in the face of stupefaction and consequent social, educational and personal problems. arising from social isolation. In an abrupt change from everyday normality, each human subject was forced to rethink their individual and social practices and relationships. In a conversation between Jean-Paul Sartre, Edith Piaf and Zygmunt Bauman, it is possible to rediscover the importance of subjectivity in time of subjectivities.

Key-words: Subjectivity; Philosophy; Pandemic Covid-19.

Folha sem data.

O melhor seria anotar os acontecimentos dia a dia. Manter um diário para que possam ser percebidos com clareza. Não deixar escapar as nuanças, os pequenos fatos, ainda quando pareçam insignificantes, e sobretudo classificá-los. É preciso que diga como vejo esta mesa, a

\footnotetext{
${ }^{1}$ Graduado em Filosofia pela Faculdade São Luiz (2010-2012) de Brusque/SC; graduado em Teologia pela Faculdade Católica Santa Catarina (2016-2019) de Florianópolis/SC; mestrando em Educação pela Universidade da Região de Joinville (UNIVILLE), com pesquisa na área de Educação e Tecnologias Digitais. Tem experiência profissional na área de Educação, na formação humana de adolescentes e jovens do Ensino profissionalizante e capacitação de lideranças e educadores. É pesquisador na área de Educação, Tecnologias Digitais e Filosofia contemporânea. E-mail: joaoedursl@gmail.com
} 
rua, as pessoas, meu pacote de fumo, já que foi isso que mudou. É preciso determinar exatamente a extensão e a natureza desta mudança (SARTE, 2015, p. 9. Grifo do autor).

Em tempos tão intensos, onde questões complexas são simplificadas e questões simples são dificilmente complexadas, é sempre importante buscar compreender nosso papel individual nas transformações à nossa volta. Importância mais filosófica em 25 de janeiro de 1932; importância mais pragmática em 2020. A partir da constatação ligeiramente responsabilizável da individualidade em Jean-Paul Sartre, parece que ultimamente tem-se esquecido a relevância e a responsabilidade de uma subjetividade.

Em A náusea, um de seus romances mais famosos, Sartre descreve as aventuras de Antoine Roquentin, um burguês insatisfeito com os rumos de sua vida que se instala em Bouville, uma cidade fictícia (nem por isso irreal), a fim de registrar a biografia de um honroso marquês. Era por volta da década de 30, quando o romance, embebido de filosofia, começa a materializar-se e circular entre os intelectuais parisienses. Mal sabia o Sr. Roquentin que nas tentativas de escrever sobre outrem escreveria sobre si mesmo. Mal sabe Sartre que no seu romance entreveríamos sua própria subjetividade; e a nossa.

Praticamente todo o diário elaborado na obra é datado, exceto a primeira página que é uma "folha sem data". Sem data, porque poderá ser o dia de hoje. Ou o de amanhã.

Um pouco longe do centro intelectual, nas periféricas e boêmias vielas da metrópole francesa, soa forte a voz de uma canarinha. Edith. Piaf. Edith Piaf.

Nas canções temperadas com melancolia e drama, talvez até sem saber, começa a cantarolar uma refinada filosofia existencial boêmia. Especialmente em L'Accordéoniste (O Acordeonista), Edith Piaf (s.d.) canta acerca de uma bela dama, que ganha a vida nos bordéis e só consegue sentir-se mais completa e amada quando descansa na contemplação dos olhos apaixonados de um acordeonista. Mal sabia Edith que nas tentativas de cantar sobre outrem cantaria sobre si mesma. Mal sabe Edith que na sua música embebida de intensidade, tristeza e paixão entreveríamos sua própria subjetividade; e a nossa.

Para que amar? Pergunta Edith. "Para nos dar alegria, com lágrimas nos olhos". Não sabemos se Piaf e Sartre chegaram a se encontrar algum dia, se trocaram olhares, se cruzaram-se em alguma via parisiense. Se não se encontraram presencialmente, o 
fizeram artisticamente. Ou filosoficamente. Sem música, diz o gigante alemão, a vida (e a Filosofia) seria um erro. Música e Filosofia. Encontro que costurou a década de 30. E de 40. E 50. 60. 70. 80. 90. 2000. 2010. 2020.

2020 !

Tempos de incerteza. Tempo de transição. Tempos de subjetividades. Tempos.

A história da Humanidade é costurada sutilmente pelas interpelações dos sujeitos que buscam, em cada fragmento do tempo, afirmar suas certezas. Por longos séculos (muito longos, segundo o tempo da consciência) as certezas estiveram tuteladas. Não precisávamos nos preocupar individualmente. Os outros optavam por nós. Sartre, porém, faz sangrar os cadáveres das tutelas. "O inferno são os outros". Sem saber ao certo o autor, faz-se gritar a antiga afirmativa: "torna-te quem tu és"; ou quem tu quiseres ser.

Estamos frente a frente com nós mesmos e nossas escolhas!

Abre-se uma porta na história universal. Por ela saem todas as subjetividades. Saem por uma porta. Pela porta de um Café. Acho que não é um Ciber-Café. É só um Café. Um Café em Bouville, a cidade pseudofictícia d'A Náusea. Dos famosos Cafés franceses, além de cafés, serviam-se doses profundas de cultura. Hoje, em tempos de subjetividades, servem-se apenas cafés gourmet's. Sartre tenta nos ajudar a redescobrir o valor das subjetividades, a partir de um café. E em tempo de transformação.

Dia 12 do isolamento social do Covid-19.

Uma xícara. Um bom café. Um livro. Um gato.

Comprei uma máquina de café expresso.

Ganhei uma cápsula de um bom café que, por sinal, é o meu favorito.

Costumo tomar meu café diário numa xícara grande. Mas na minha nova máquina apenas encaixam-se as pequenas xícaras. Precisei recorrer ao acervo materno. Escolhi uma xícara pequena, de formato uniforme, inteira adesivada de bolinhas. Ela me parecia comum. 
Dia 13 do isolamento, segundo dia com a máquina nova, mais um café na xícara de bolinhas.

Dia 14 do isolamento, terceiro com minha máquina.

Decidi por mais um café no começo da noite. Estava sentado no sofá. Meu gato começava a se aninhar no meu colo. Na mesa de centro da sala estava meu livro favorito.

Queria a companhia do gato. Queria ler o livro. Mas precisava de um café.

Entediado com aquela xícara de bolinhas, decidi escolher outra. Precisava ser pequena. Quem me dera aquele café numa xícara grande! Mas só cabia a pequena na nova máquina. De repente meu olho pousa sobre uma xícara.

\section{Uma xícara!}

Uma xícara. De contorno barroco. Pintada à mão. Com uma rosa só. Borda dourada. Que xícara! Era do enxoval do casamento dos meus pais. A xícara já tem quase 50 anos.

Liguei a máquina. Completei com água. Coloquei a cápsula do café. Encaixei a xícara.

Era muito interessante ver a xícara com contornos barrocos numa máquina de traços modernos. Sobreveio-me instantaneamente a saudade dos lugares mais especiais que passei. Me lembrei das grandes metrópoles cosmopolitas com seus esplêndidos bairros históricos e seus becos boêmios. Quanta lembrança! Mas foi rápido. Uns 15 segundos. Café pronto! Voltei para o sofá. Sentei-me. O gato já voltou para o meu colo. Peguei o livro.

\section{Um livro!}

Um livro. Um conto norte americano. Era sobre um gato preto. Este era indesejado pelo dono. Tinha um olho só. Num ataque de fúria, seu dono o rebocara na parede de casa. Era um gato. Era um conto. De terror. Olhei meu gato. Sobreveio-me 
uma vertigem. Deixei o livro de lado por enquanto. Olhei para o gato. Olhei para a xícara. E fiquei fixo na xícara.

Uma xícara. De contorno barroco. Pintada à mão. Com uma rosa só. Borda dourada. Que xícara! Congelei por mais alguns segundos.

Uns segundos!

Uns segundos. Que estranho! De novo uma vertigem. Um estranhamento. Era a rosa pintada na xícara. Era uma só. Mas era estranha. A rosa estava pintada delicadamente, para aquela xícara, parecendo ser pensada para estar naquele exato lugar, perto da alça. Mas para dentro! Para o lado de dentro de quem segura, no caso, de mim mesmo. E o restante da xícara? Branca! Toda branca. Só a borda com um filete dotada. Mas toda branca. Só aquela única rosa a consolava.

Mas por que? Por que a rosa, logo a rosa, escondida para dentro? Olhando só para mim? Por que não desabrochara para quem me visse tomando dessa xícara? Recorri a explicações dentro da minha consciência. No meu mapa geográfico literário lembrei de Bouville.

\section{Bouville.}

Janeiro de 1932.

Sobreveio-me a sensação de que aquela xícara estava ali só para mim. Uma espécie de valorização daquela minha experiência subjetiva, capaz de fazer com que a minha existência fosse única, fosse especial, fosse memorável, só para sentir aquele café, naquela xícara.

A experiência daquele café, naquela xícara, da contemplação daquela flor e daquele aroma fez com que as decisões subjetivas fossem tão únicas e especiais que pudesse escolher por mim, pelos outros, por todo o mundo. E se tivesse que escolher de novo, e de novo, e de novo... escolheria aquela experiência, daquele café, naquela xícara.

Uma xícara. Um café. Uma flor. Uma vertigem. Uma certeza; subjetiva. 
Uma certeza subjetiva.

Nos tempos turbulentos de uma pandemia mundial, há notícias de que, quando a existência se voltou para a contemplação subjetiva, isolada e doméstica, algumas águas ficaram mais despoluídas, alguns lugares tiveram ar mais puro, alguns animais puderam gracejar em lugares antes inimagináveis. Subjetividades em destaque, recomendadas para a sobrevivência. Um ótimo exercício existencial: isolar-se consigo, tendo de encarar a si mesmo. Cada um com sua subjetividade, para salvar todo mundo.

Estamos novamente frente a frente com nós mesmos e nossas escolhas; se algum dia já ousamos estar.

A experiência mundial no tempo da disseminação da Covid-19 foi capaz de expor a maior das verdades incômodas da existência humana: somos frágeis, nem sempre lúcidos; e todo cuidado é pouco para prolongar nossa experiência vívida humana. Tempos de transição trazem muita incerteza; e tempos incertos tendem a ser decisivos. Uma redescoberta da subjetividade se faz fundamental para conservar lúcida a existência que busque encontrar o mínimo de sentido ou de empatia.

O confinamento revelou outras tantas verdades incômodas: não estávamos mais tão acostumados conosco; não lembrávamos mais como era estar em casa; sequer sabíamos o que existia em casa; e em nós. Um gato me esperava; um livro clamava por minha leitura; um café é importante; uma xícara é surpreendente; eu sou importante.

Êxodo da minha subjetividade no tempo das subjetividades.

Exodo.

Subjetividade.

A xícara fala de mim; o café fala de mim; o gato fala de mim; o livro fala de mim; a vertigem fala de mim; a casa fala de mim; e eu não percebia mais a mim mesmo.

Parece que o modo como viva já não dissesse mais nada sobre mim mesmo. $\mathrm{O}$ que mais dava sentido acabara por perder-se num emaranhado de non sense. Talvez o sentido ainda estivesse ali; eu que havia me perdido no emaranhado de muitos sentidos existentes; ou de nenhum. 
É um tempo de transição. Tempo de incerteza; e de verdades incômodas.

A partir de Sartre é possível pensar um novo humanismo possível, censuradamente inclusivo pela náusea da existência. Junto com Edith Piaf, esse humanismo ganha ritmo, leveza, dramaticidade incontestável. A afirmação radical da subjetividade só é possível através da afirmação da alteridade. Sou um porque há o outro. Sou um universo, minúsculo, entre galáxias.

O que esperar de um tempo pós-pandemia?

Uma folha de diário datada, uma anotação de um dia específico nos ajuda a transcrever o fenômeno como ele está acontecendo, investigar o contexto, pensar o presencial, atentar aos detalhes, dar atenção aos contatos. Tudo isso fala da capacidade de conseguir capturar o "isto", o fenômeno cru, o que está acontecendo na dobradiça da História. É preciso desenvolver, mais do que nunca, a nossa capacidade epistemológica da complexidade social. É preciso captar a complexidade e a subjetividade, a coisa e si mesmo, a coisa em si mesma. Isso se faz a partir da clareza dos sentidos das coisas, das intersubjetividades, da interculturalidade crítica ou através de uma xicara de café.

\section{Uma xícara.}

Uma xícara barroca. Uma xícara barroca com uma flor. Uma xícara barroca com uma flor voltada para mim. Uma xícara sartreana. Uma xícara que me faz pensar mais em mim mesmo.

Certa vez, lembro-me com lucidez, numa aula de sociologia no tempo da graduação, um professor muito idoso, do qual quase não se entendia o que balbuciava entre muitos nomes e datas (já que era um professor muito "histórico" daqueles que fazia-nos decorar data por data) precisara categoricamente o início da "pósmodernidade". Não sei qual foi o teórico que ele citou naquele dia, mas tardiamente ouvi o mesmo exemplo numa entrevista de Zygmunt Bauman (2015) pelo YouTube. Aquele meu ancião professor dissera que a pós-modernidade começou numa quartafeira à noite, por volta de 1980. Foi num programa de TV parisiense. Era uma estreia de 
um novo programa. A apresentadora vestia-se modestamente. Inaugurava-se a modalidade de "programas de auditório". Os convidados estavam um pouco tímidos com aquele entorno do programa "ao vivo". Havia uma câmera só para a transmissão, pois os recursos eram escassos ainda. Era uma entrevista. Um talk-show.

Quarta-feira à noite. Noite de outono. Em Paris.

Vivienne.

Nesse programa inovador, uma entrevista com Vivienne, uma mulher comum, ao vivo na TV, na presença de milhões de expectadores. Logo no início da entrevista ela afirmara que nunca havia tido um orgasmo em seus longos anos de casamento. E ainda dissera o nome do seu marido: Michel. E mais: ele sofre de ejaculação precoce.

(Silêncio).

A afirmação chocou a plateia. O exemplo chocou a turma, acostumada com as teorias complexas da Filosofia. Deixou-nos sem entender muito. Era o clima perfeito para terminar uma aula em alto estilo, como num grande "Café Filosófico". Mas há explicações.

A explicação está em Vivienne.

Vivienne.

Vivianne expõe publicamente um tabu. Por ser mulher, por sofrer uma desilusão, por ser subjugada, por falar sobre sexo, ninguém jamais esperaria aquilo de Vivienne.

Vivianne, a mulher comum de Paris, inaugura a pós-modernidade.

Um assunto que poderia no máximo ser dito no confessionário ao padre, que faz voto de silêncio e retidão, e morreria ali mesmo, visto o segredo sacramental obrigatório, agora é dito a plenos pulmões num "novo confessionário", num talk-show, o novo confessionário da "sociedade do espetáculo". Segredos que eram imersos numa aura divina e sobrenatural agora são humanizadas ao extremo das consequências de uma existência. Vivienne grita: “eu existo" e "nunca tive um orgasmo". 
"Nunca tive um orgasmo".

Um orgasmo.

É o grito da pós-modernidade.

O que Vivienne teria a nos dizer hoje? O que o "eu do presente" teria a dizer para o "eu do futuro"? Que conselho para o pós-pandemia na pós-modernidade seria o ideal? Ainda não sabemos; nem sabemos se existe.

O que sabemos que existe, ao menos sobrevive: o "eu do presente", imerso em paradoxos pós-modernos.

O tempo de agora, especialmente este marcado por problemas não solucionados e reviravoltas não esperadas, serve para deixar nossa fragilidade humana exposta, e fazer-nos repensar os rumos das utopias de onipotência, especialmente assistidos nos cenários políticos, econômicos e dos grandes discursos fascinacionais. Assim como fez Vivienne, uma pandemia expôs nossa vergonha e finitude inexorável. Diante disso nos resta reinventar nosso "normal", nossas perspectivas e percursos; ou sucumbir na tristeza de nossa própria fragilidade. A admiração com uma xícara, com um dia chuvoso, com um programa de TV chocantemente real ou com outras subjetividades banais podem se tornar epifanias de um novo modo de ver o mundo ou de rever a si mesmo.

Sartre, Piaf, Vivienne, Michel, uma xícara e eu.

$\mathrm{O}$ advento da subjetividade num tempo de subjetividades.

\section{REFERÊNCIAS BIBLIOGRÁFICAS}

BAUMAN, Zygmunt. O que é pós-modernidade? Trad. Wilney Ferreira Giozza. S.1.: Fronteiras do Pensamento; Prod. Telos Cultural, 12 out. 2015. Disponível em: <https://www.youtube.com/watch?v=aCdUuQycl6Q>. Acesso em: de 20 maio de 2020.

PIAF, Edith. L'Accordéoniste. Composição de Michel Emer. S.d.. Disponível em: <https://www.letras.mus.br/edith-piaf/550069/>. Acesso em: de 15 maio de 2020.

SARTRE, Jean-Paul. A náusea. Trad. Rita Braga. Rio de Janeiro: Nova Fronteira, 2015. (Coleção 50 anos). 